of the small flying lizard. Mr. G. A. Carter's "Grolip of Red-deer" (I 405$)$ is not a great success, but it will probably look better when executed in silver. There is much merit in Mr. W. Prehn's "Polar Bears" (1455), in which the artist has coloured the snouts and slightly washed the limbs of the animals with yellow to relieve the deadness of such a mass of wbite; an excusable innovation in the present instance. And last in order we come to two admirable models of "A Wild Boar" (I5OI), and "A Bear" (1507), by Mr. Joseph Wo'f, whose repulation as a delineator of animal life with the brush is unrivalled, but who has never till now turned his attention to modelling The attitude of the boar is excellent : his face is devoid of any expression, although he has evidently partaken of some vegetables whose remains lic at his feet, but withal the, $e$ is no sign of $\in$ njoyment or satisfaction. It is otherwise with the bear, who has been devouring honey-comb, and who is now licking his chops with an expression worthy of a gourmand, showing that the good things of this life are by no means wasted upon a gentleman of his appreciation. And with this we close our notice of animal life at the Academy, congratulating artists in general upon the increasing tendency to paint their subjects from nature instead of evolving them out of their own inner consciousness.

TwO NATURALISTS

\section{THE ETHNOLOGY OF THE PAPUANS OF MACLAY COAST, NEW GUINEA}

I December 1873, when at Batavia, I received from 1 the Russian travcller, Von Miklucho-Maclay, reprints of two articles upon the East Coast of New Guinea and its inhabitints, of which I made a short abstract for NATURE (Feb, 26, I874), during my voyage from Jara to Atchin. The following is the substance of one of two supplementary papers on the same subject, ${ }^{1}$ which have been lately sent to me, by Dr. Maclay, from Johore, on the Maldy peninsula; which, it would be imagined, should be all the more interesting, as much which is, to say the l ast, doubtful, has lately been published about $\mathrm{New}$ Guinea and its natural productions.

The former papers dealt with the individual characters of the Pafuans, while in the present article the food, weapons, dress, dwellings, and daily live of this people will be treated of.

The Food of the Papuan. - That of the inbabitants of Maclay Coast is principally of a non-animal nature, consisting of fruits and vegetables, of which a list is subjoined in the order of their domestic importance.

The Cocoa-nut (munki). This plays a most important part in the economy, as it is obtainable all the year round. The trees are seldom to be met with in the mountain villages, but are numerous on the shores of the neighbouring islands, though here they are confined to plantat:ons around the houses. A favourite dish which never fails at feasts is munki.la, a kind of porridge made of the grated kernel of the nut steeped in the so.called "milk." Curiously enough, the preparation of cocoa-nut oil is unknown.

The Dioscorea (ajan) is much cultivated in the plantations, and is in condition for lood from August till January. It is boiled in water, or when this is difficult of carriage, roasted in ashes. In forms the principal article of dit during the above-ramed months.

The Collucas a (bau) is the main article of food from March to Augus:. Like the ajan, it is either boiled or baked. Pounded up with grated roasted cocoa-nut, it is made into a kind of cake, which is in great request at feasts. The leaves of the plant are also eaten.

The fruit of the Convolvulus (degargol), of which there are two varieties, one red, the other white, is principally

I "Ethnolcgische Bemerkungen über die Papuas der Maclay.küste in Neu Gunea." Reprinted from the Natuurkundis Tija:chrift of Batavia. in season in September and October, and is either stewed or baked.

Although no less than eight or nine varieties of Banana (moga) were met with by Miklucho-Maclay, owing to its limited cultivation, the fruit is a comparative rarity. The lower part of the stem and the roots of the young plants are also eaten.

On account of the rare occurrence of the Palm affording it, sago (buam) is rather a dainty, seen only at feasts, than an article of daily diet.

The Sugar-cane (den), which attains a magnificent growth in New Guinea - the edible portion being not infrequently fourteen feet high-is chewed with the greatest zest by men, women, and children, from October to February.

The Bread-fruit (boli), though not particularly sought after, is collected and eaten stewed or roasted.

The Orlan is the fruit of a tree which Dr. Maclay had no opportunity of seing. This fruit is hung in great baskets upon the trees in the forests. From the pulp and the kernel of the crushed seed there is derived by fermentation an acid unpleasantly smelling sauce, which is considered a great delicacy.

The Canarium commune (kengar) is collected in May, June, and July, dried, and its seed stored.

The fruit of the Prndanus (Screw Pine) and Mangifera (mango) also occurs, but very sparingly, on Maclay Cozst. Animal food is of but rare occurrence. The following animals are, however, the most usual sources of food :-

The Pig.- This, a descendant from the wild New Guinea species, is bred in the villages. When young it is striped, but with age it becomes black. The ears are erect, the snout sharp, and the legs long. Pigs are only killed on festal occasions, and then one suffices tor two or three villages.

Dogs are kept by the Papuans principally for the sake of their fesh, which, though of fairly good flavour, is, nevertheless, somewhat dry.

The flesh of the Cuscus ${ }^{1}(m a b)$ is considered a great dainty, although it has a strony smell.

Fowls, although they occur in the villages, are but seldom eaten ; and, as they exist in a semi-wild state, their eggs are not of ten to be obtained. During a stay of fifteen months Dr. Maclay only saw two egys in the various villages which he visited.

From the large lizards (Monitors) a white and tender meat is obtainable.

All insects without exception, especially large beetles, are eaten, either raw or cooked, by the Papuans.

As regards fishes, the larger are caught in nets, while the smaller are killed by harpoon at night time.

Various molluscs and other shell fish are collected on the coral reefs at low water by the women and children of the villages.

As the existence of salt is unknown here, the Papuans cook their food with a little sea-water-uenerally onethird to two-thirds fresh water-and the inhabitants of the hills never omit to take away with them a bamboo filled with sea-water when they visit the coast. The Papuans have, nevertheless, a substitute for salt, for they collect the tree-trunks which, after soaking for a while in the sea, are cast up at high tides, dry and burn them, and thus procure therefrom a saitish tasting ash.

The manufacture of intoxicating drinks is, moreover, not unknown among the Papuans. They take the stem, leaves, and especially the root, of a certain shrub called "keu" (Piper methisticum?)! this they chew, and the resulting mass, when sufficiently masticated, is spat out with as much spittle as possible into a cocoa-nut shell. A little water is added to this, and, after the dirty greenlooking brew has been filtered through some grass, the tillrate, which is very bitter and aromatic, is drunk off. 'This liquor does not taste particularly good, as is proved by 
the grimaces of the natives as they drink; very little, too, goes a long way, for a small wine-glassful suffices, in half an hour, to make a man unsteady upon his legs. Old people only are allowed to indulge, for it is strictly forbidden by custom to women and children. The Papuan $k_{c} z$ appears to be identical with the kazua of the Polynesians, only these latter add more water.

The cuisine is in every way more elaborate than among the Polynesian aborigines, both as regards variety of dishes and the use of earthenware. Though food is mostly prepared with sea-water. the Papuans, nevertheless, know how to roast flesh or fish, or bake it, enveloped in leaves, in the ashes. As on account of the climate cooked food will not keep long, the Papuans either roast (e.g. in the case of the Collocasia and Dioscorea) on the morrow the remnant of that which is stewed to-day, or vice vers $\hat{a}_{\text {, }}$ as is the case with fish, which is fried immediately after it is caught, and stewed with vegetables on the following day. By this means the millions of mildew spores and mycelia which in a few hours invade and pervade all food, whether roast or boiled, are arrested in development, and so rendered harmless. The men help the women in the preparation of food; in fact, on festal occasions and on the entertainment of an honoured guest, this is done entirely by the men alone. On ordinary occasions the husband cooks for himself alone, and the wife for herself and the children apart. The two sexes never eat at the same hearth, or o!t of the same dish.

The domestic utensils consist of earthenware pots of various sizes, and of wooden dishes. They are of the following varieties:-

Pots $(w a b)$. - These are usually of the same shape; being almost round, and tending somewhat to a point at the bottom. They are made in a few coast villages and in the neighbouring islands, and, though generally prepared with great care, show but few ornamentationsthese consisting either of strainht lines, rows of dots, or small curves, evidently impressions of the nails. The mountain people do not unclerstand this manufucture, and so must obtain their pots either by present or by barter.

The wooden utensils (tabir) consist of large round or oval plates and bowls, and seem very cleverly made, considering that the only tools used in their construction are either of stone or of bone. They are finally smooth polished with fragments of shells, and a black dye is then rubbed in. The "tabir" forms, with the weapons, the most important possessions and articles of barter for the Papuans.

The shells of the cocoa-nut ( gamba) are used as plates by the lower members of a family, as it is only for the father of the family or for a guest that food is served in the large wooden bowls.

A kind of fork (hassent) is used at meals, consisting of a pointed stick. Three of these are sometimes tied together, and are then generally carried in the hair, as they also serve the purpose of head-scratchers.

The kai is a kind of spoon made from a cocoa-nut or mollusc shell; while the schilizupa is made from a flat splinter of kangaroo or pig's bone, and can be used either as a knife or shallow spoon.

A very important implement-the jarur - is made merely from a smooth shell, in which teeth are cut with a stone. This is used to grate the albumen of the cocoanut, which is usually only eaten in this form.

The implements and arms are as follow :-" If we look at," says Maclay, "their buildings, their firogues (canoes), their utensils, and their weapons, and then cast our eyes upon the stone axe and some fragments of pebbles and shills, we must perforce be struck with astonishment, if only at the great patience and skill displayed by these savayes." The axe, which, though their chief implement, is, no one will deny, a tool simple enough, consists of a hard, grey, green, or white stone, which has become smooth and sharp by long polishing. Hatchets have been seen by Maclay in the "Archipelago of Contentment," which were made out of a thick clam (Tridacna) shell, instead of from stone. A portion of the stem of a tree, which has a branch passing off at an angle, somewhat like the numeral 7 , is hewn off, and upon the branch, which has been cut off short and shaven flat at the top, the stone is laid horizontally and bound fast with lianas or various kinds of tree-barks. Such an implement can only be used to advantage by one accustomed to handle it ; otherwise, either the stone is broken or nothing results. The aborigines, however, can with their axe, having a cutting edge of only two inches in breadth, fell a tree trunk of twenty inches in diameter, or carve with the same really fine figures upon a spear. Every village possesses a large axe or two having a cutting edge about three inches broad, and which is wielded with both arms, while the ordinary axe of two inches edge is employed with the right arm only. The stone of the hatchets, a kind of agate, is confined to the mountain people, and is not found in superfluity. Each adult is in possession of only one good axe, the larye ones being kept by their owners as things of the utmost value and rarity.

Fragments of flints and of shells are used to put the finishing touches to work done in the rough with the stone axe, the shells being preferred to the flints, as being not so brittle. All sorts of devices can be carved upon bamboo with shell fragments. The great combs of the Papuans and the bamboo boxes in which the lime for betel-chewing is kept, as well as their arrows, furnish instances of this art.

The dongan is a pointed or flatiy split bone, having the shape either of a dagger or of a chisel. For the firstnamed pattern the bones of the cassowary and (but rarely) those of man are used, while those of pigs and of dogs are employed for the latter form. The "dongans" are used for cutting either raw or cooked fruit, and are generally carried on the arm, being supported by the armring.

A knife is made from the bamboo by removing the inner woody fibres at the edge of a fragment, so that only the sharp siliceous outer part is retained. With this, meat and fruit and vegetables are cut up, while the dongan is never used for cutting, but only for splitting and piercing.

The weapons comprise-

I. The chadga, a spear used for throwing, about $6 \mathrm{fr} .8 \mathrm{in}$. in length, and made of a hard, heavy wood. It is the most dangerous and most universally used of the Papuan weapons.

2. There is also a longer, but lighter, spear, the serwaru, tipped with a sharpened piece of bamboo, which, after a victim has been struck, breaks off from the shaft and remains in the wound.

3. The aral is a bow, about two yards long, the string of which is made from bamboo.

4. The arrows, aral-ge, are about one yard long, of which the tip is as much as a third or a quarter of the shaft in length, and is sometimes provided with barbs.

5. A most dangerous kind of arrow, palom by name, is of the same size as the preceding, but resembles the serwaru in having a broad bamboo tip. For catching fish there is yet another variety of arrow, the saran, provided with four or five points. When fishing by torchlight, the Papuans use the jur, a hatpoon with numerous tips of hardened wood, and furnished, in order that it may not sink, with a bamboo shaft.

The inhabitants of the neighbouring islands-Bili-Bili, Fam-Bomba, Griger, Tiara, \&c.-possess in addition large shields, about a yard in diameter, made out of a hard wood, and ornamented with carvings. Miklucho Maclay's coast neighbours had nothing of the kind. In some of the villages he saw long flat sticks, about a yard 
and a half in length, which must be wielded, much like the large ancient swords, with two hands. ${ }^{1}$

Sling-stones are also in use in time of war. The principal weapon of warfare, however, is the above-mentioned chadg $\alpha$, which is dangerous up to a range of from thirty-five to forty paces. The arrows can scarcely be considered dangerous above fifty paces range, because they are too light. In war time, and in hog-hunting, the tips of the spears and arrows are rubbed with a red earth, but the Papuans in this neighbourhood do not poison their arrows.

Regarding the dress and ornaments of the Papuans: the sole article of clothing of the men is the mal, a kind of cloth prepared from the bark of trees, having a length of more than three yards and a breadth of about a quarter of a yard. This article of dress is manufactured in a way similar to that of the tapas of the Polynesians; the outer layer of bark is detached, and then beaten with a piece of wood upon a stone until it becomes soft and supple, after which it is dyed with a red earth. It is worn thus: one end having been held fast on the belly, at the navel, the cloth is passed between the legs, and then carried several times round the waist, the end being finally tied with the first end in a knot at the back. As much traction is exercised upon the part which is pushed between the legs, the anterior end comes to hang down in front. The corresponding dress of the females, also called mal, consists of fringes about half a yard long, fastened to a girdle, which hangs down in thick clus ters as far as the knees, and does not embarrass the movements of the body. This garment is generally dyed in black and red horizontal stripes. In some villages the mal of the girls up to the time of marriage consists of a girdle, to which two bunches of dyed bast are attached, one hanging down in front, the other over the middle of the buttocks; and when they sit down they carefully pull the hinder and longer bunch between the legs. These young ladies also carry on either side of their buttocks ornaments of shells and coloured fruit-stones. Besides the mal, the Papuans possess long and broad pieces of cloth, similarly prepared, which they wear over the shoulders in the night and early morning, as a protection against cold.

The ever-constant companions of the Papuan are his jambi and his gmn. The former is a small bag carried round the neck, containing tobacco and various small articles; while in the latter, which is larger, and is slung over the left shoulder, he carries a box of quicklime for betcl-chewing, his jarur, schiliupa, and kai, shells, and bamboo boxes containing red and black dyes, and other necessaries. These bags are woven out of variously coloured threads, and ornamented with shells.

The men carry on the upper arm, above the biceps, bracelets called sagiu, artfully woven out of bark or grass, and ornamented with shells. Stuck in such a ring the dongan is carried. Similar rings, or "bangles"-sambasagiu-are worn above the calves. A highly prized ornament, worn hanging from the neck over the breast, is the bul'ra, wild boar's tusk.

The men also wear broad earrings of turtle-shell or of wood, or in default of these, pieces of bamboo, longish stones, or flowers. The women have two kinds of earrings. From either ear-lobe hangs one or several rings; or from the upper edge of one ear there passes a cord across the forehead to the corresponding part of the other ear, while from either extremity of the cord a bundle of white dogs' teeth hangs down on the side of the necis. The women also have two bags-nangeli-gun - which are much larger than those of the men, and are carried on the back, slung by a band round the forehead. In one of these fruit is brought daily from the plantations into the villages, while in the other the newborn children, or else young pet pigs or puppies, are carried.

$$
\text { J. C. Gaiton }
$$

\section{(To be continued.)}

${ }^{x}$ Could these not be used, like similar weapons employed by certain tribes in the "heart of Africa," for parrying blows?-J. C. G.

\section{THE MUISEUM OF COMPARATIVE ZOOLOGY,} CAMBRIDGE, U.S.A.

THE Report of the Museum of Comparative Zoology for the past year, which has just reached this country, is of great interest, as it gives us an account of the way in which the supporters of this noble Institution have endeavoured to meet the blow it suffered by the premature death of its founder. The Penikese School of Natural History succumbed, we know, after a faint struggle, but it does not at all appear that the Museum of Comparative Zoology is likely to follow its example. A fund of 260,600 dollars has been raised by public subscription, as a memorial to Agassiz, which is to be devoted to the completion and endowment of the Museum, and the State of Massachusetts has granted a further sum of 50,000 dollars to the like object. As more than the amount, stated to be necessary for the purpose has thus been received we trust there can be no doubt that the desired object will be attained, and the building finished and its stiff endowed according to the plans formed by the late Professor Agassiz.

The general work of the assistants in the Museum of Comparative Zoology during the past year, has we are told, "as usual consisted mainly in preparing materials for exhibition, and packing the duplicate collections for exchange." The late Professor Agassiz accumulated, as is well known, enormous masses of specimens of every class in alcohol. But the present Report says :--

"The great difficulty of preserving alcoholic collections, the unpleasant nature, and enormous expense of the work make it imperative, not only for storage, but still more for exhibition purposes, that they should be restricted to a minimum, and limited, as far as possible, to those classes where no other mode of preservation is practicable. The constantly increasing facilities of travel, the comparative economy with which fresh specimens can be studied, the superiority of such work (with proper appliances) to that of the Museum, the daily increasing number of workers who are able, on the sea-shore or in the field, to produce results unattainable by Museum study alone, show that the time has come when large collections must naturally be supplemented by zoological stations. These, when once established at properly selected localities, will enable Museums to dispense with much that is now exceedingly costly. They will become, for certain departments at least, chiefly depositories where the record of work done at the stations-the archives of natural science, so to speak-will be preserved ; so that, while their usefulness for the general instruction of the public and of our higher institutions will not be diminished, they must hereafter be useful to the original investigator in a somewhat more limited field."

There can be no doubt of the sagacity of these remarks. They should be well considered by the supporters of the Aquariums now springing up in every direction, which might easily be so arranged as to be useful also as Zoological Stations like that at Naples.

The most important addition made to the collection at Cambridge in 1875 , appears to have been that formed by $\mathrm{Mr}$. Alexander Agassiz during his expedition to Peru and Bolivia. This, we are told contains a "fair representation of the Fauna of the high plateau in which Lake Titicaca is situated." A preliminary account of the materials collected is now being published in the "Museum Bulletin." The fishes and reptiles will be described by Mr. German, the fossils by Prof. O. A. Derby, the crustacea by Mr. Faxon, the birds and mammals by Mr. Allen, and Mr. Agassiz hopes, himself, to be able to give a short account of the physical geography and geology of the district.

I Annual Report of the Trustees of the Museum of Comparative Zoology at Harvard College, in Cambridge : together with the Report of the Curator to the Committee of the Museum, for 1875 . Boston, 1876 . 